\title{
Sprawozdanie z konferencji naukowej „Nie/porozumienie, nie/tolerancja, w(y)kluczenie w języku i kulturze" (Wisła, 18-20 września 2019)
}

\author{
A Report from the Academic Conference "Nie/porozumienie, \\ nie/tolerancja, w(y)kluczenie w języku i kulturze" \\ (Wisła, 18-20 September 2019)
}

W dniach 18-20 września 2019 roku w Wiśle odbyła się konferencja naukowa zatytułowana „Nie/porozumienie, nie/tolerancja, w(y)kluczenie w języku i kulturze”. Wydarzenie zostało zorganizowane przez Zakład Historii Języka Polskiego oraz Zakład Lingwistyki Tekstu i Dyskursu Instytutu Języka Polskiego im. Ireny Bajerowej Uniwersytetu Śląskiego $w$ Katowicach. Wzięli w nim udział badacze reprezentujący ośrodki naukowe z całej Polski. W konferencji uczestniczyła także dyrektor Instytutu Języka Polskiego im. Ireny Bajerowej - Mirosława Siuciak, która wraz z organizatorami Ewą Biłas-Pleszak, Arturem Rejterem, Katarzyną Sujkowską-Sobisz i Wiolettą Wilczek dokonała otwarcia spotkania naukowego.

Uczestnicy mogli wziąć udział $w$ obradach plenarnych i w sekcjach panelowych, podczas których wygłoszono prawie trzydzieści referatów. Wystąpienia pierwszego dnia zostały podzielone na dwie części. Rozważania naukowe otworzył referat Urszuli Sokólskiej (Uniwersytet Łódzki), która przedstawiła wnioski płynące z analizy semantycznej słów tolerancja i tolerancyjny. Punkt wyjścia stanowiły opinie reprezentantów różnych środowisk (politolog, filozof, duchowny) na temat tolerancji. Referentka poddała oglądowi badawczemu definicje słownikowe dwóch wymienionych leksemów i zwróciła uwagę na różnorodność elementów występujących $w$ tychże definicjach, między innymi takich, jak sposób myślenia, religia, sposób postępowania czy sfera seksualna. Kolejny wykład wygłosił Mariusz Rutkowski (Uniwersytet Warmińsko-Mazurski), który poruszył temat strategii wykluczenia za pomocą nazw własnych. Prelegent przedstawił przykłady zmiany, eufemizowania oraz celowego pomijania onimów na różnych poziomach dyskursów politycznego, historycznego i medialnego. Dowiodło to, że wykluczenie za pomocą nazw własnych jest skutecznym działaniem społecznym znanym od czasów starożytnych. Magdalena Steciąg (Uniwersytet Zielonogórski), której wystąpienie zamykało pierwszą część obrad, poddała analizie język demonstracji publicznych kobiet $w$ Polsce $w$ latach 2016-2017. Autorka odniosła strategie antydyskryminacyjne i dyskredytujące obecne w przekazie werbalnym protestujących kobiet do poprawności politycznej, biorąc pod uwagę aspekty: semiotyczny, aksjologiczny i etykietalny.

Po krótkiej przerwie kontynuowano obrady plenarne. Rafał Zarębski (Uniwersytet Łódzki) w referacie Murzyn, Czarny, Kolorowy - o nazwach ludności czarnoskórej w dawnej i współczesnej polszczyźnie dokonał analizy funkcjonalnej leksemów należących do pola 
semantycznego 'nazwy człowieka o ciemnej/czarnej skórze’. Przeprowadzona obserwacja zobrazowała, jak słowa, będące pierwotnie neutralnymi, pod wpływem uwarunkowań kulturowych zyskały negatywne konotacje i zaczęły funkcjonować jako narzędzia wykluczenia. Tomasz Lisowski (Uniwersytet im. A. Mickiewicza) uczynił przedmiotem swojej analizy własny przekład koreańskiej piosenki Achim iseul, która stała się protest songiem i symbolem niezgody na niesprawiedliwość rządów dyktatury wojskowej. Referent ukazał trudne zadanie, jakie staje przed tłumaczem, który za pomocą rodzimych środków językowych stara się oddać bogactwo sensów wpisanych w tekst należący do obcej mu kultury $w$ tym wypadku kultury koreańskiej. Jako ostatnia pierwszego dnia zabrała głos Irmina Kotlarska (Uniwersytet Zielonogórski), która poddała oglądowi badawczemu materiały do nauki języka angielskiego dla polskich emigrantów wojennych w Wielkiej Brytanii w latach 40. XX wieku. Mówczyni zaprezentowała różnorodne zabiegi i środki językowe służące przedstawieniu różnic kulturowych między kulturą polską a anglosaską. Wystąpienie dowiodło, że sposób doboru i prezentacji elementów kulturowych sprawiał, iż omawiane teksty stawały się źródłem postaw i wartości godnych naśladowania wśród emigrantów.

Referaty drugiego dnia zostały podzielone na dwie sekcje, z których pierwsza składała się z trzech wystąpień. Wykład Anny Lenartowicz-Zagrodnej (Uniwersytet Łódzki) dotyczył relacji między polszczyzną a językami obcymi (łaciną, greką, niemieckim) prezentowanych przez leksykografów. Referentka skupiła się na elementach, które zbliżały polszczyznę do języków obcych i które ją wyróżniały wśród nich, a także na zadaniach i miejscu języka polskiego w życiu. Lucyna Warda-Radys (Uniwersytet Gdański) poruszyła temat oswajania hejtu w języku polskim i kulturze. Badaczka przeanalizowała rozwój semantyczny samego leksemu hejt, a także powstanie rodziny wyrazowej i polskich odpowiedników omawianego wyrazu. Ponadto uwaga została zwrócona na rosnące przyzwolenie społeczne na publiczne dawanie upustu negatywnym emocjom. Obrady w tej sekcji zamknęła Karolina Lisczyk (Uniwersytet Śląski w Katowicach), która przedmiotem swojego wystąpienia uczyniła zakresy znaczeniowe, konteksty użycia, a także konstrukcje składniowe i połączenia leksykalne, w których używane są wyrazy tolerancja i tolerancyjny. Prelegentkę interesowała szczególnie potoczna odmiana polszczyzny.

Obrady w drugiej (równoległej) sekcji otworzył referat Pawła Grafa (Uniwersytet im. A. Mickiewicza) Interpersonalne trombosis. O współczesnych aporiach semantyczno-komunikacyjnych. Przedmiotem analizy stał się kryzys komunikacyjny naznaczający współczesność, którego powodem są liczne aporie: cielesne, etyczne, estetyczne, językowe i tożsamościowe determinujące rozumienie siebie $w$ świecie oraz rozumienie rzeczywistości. Beata Grochala (Uniwersytet Łódzki) w wystąpieniu pokazała, w jaki sposób (zwłaszcza $w$ perspektywie mediolingwistycznej) przejawia się dyskurs wykluczenia w sporcie. Referentka zaprezentowała przykłady manifestacji, które odnaleźć można na płaszczyźnie struktur językowych, semantyzacji pewnych pojęć i tematyzacji (lub jej braku) określonych wydarzeń. Jako ostatnia w tej sekcji głos zabrała Kamila Kuros-Kowalska (Uniwersytet Śląski w Katowicach), która poruszyła zagadnienie wielokulturowości i jej wpływu na język. Lingwistka na podstawie rozumienia najpopularniejszych słów młodzieżowych z ostatnich lat wśród uczniów szkół polonijnych $w$ Wielkiej Brytanii starała się odpowiedzieć na pytanie o to, czy po powrocie do kraju emigranci będą w stanie porozumieć się z rówieśnikami $w$ rodzimym języku. 
Sprawozdanie z konferencji naukowej „Nie/porozumienie, nie/tolerancja, w(y)kluczenie...

Po krótkiej przerwie obrady w dwóch równoległych sekcjach były kontynuowane. Sekcja pierwsza obejmowała cztery referaty. Pierwszy z nich wygłosiły Danuta Kowalska i Magdalena Pietrzak (Uniwersytet Łódzki), które, wykorzystując genologiczne i dyskursywne instrumentarium badawcze, prześledziły karierę Heleny Modrzejewskiej w War-

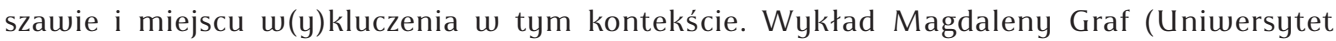
im. A. Mickiewicza) poświęcony został różnym aspektom komunikacji na forach i blogach o tematyce dotyczącej zaburzeń odżywiania. Rozważania te zostały osadzone we współczesnym dyskursie cielesnym. Prelegentkę interesowała sfera apelatywna oraz warstwa onimiczna. Jako trzecia referat wygłosiła Renata Bura (Uniwersytet Jagielloński), która oglądowi badawczemu poddała objaśnienia nawiasowe w tekstach górnołużyckich. Referentka rozważała, czy objaśnienia te można traktować jako przejaw tolerancji, czy konieczności. Omawiany problem został przeanalizowany $w$ dwóch perspektywach: synchronicznej i diachronicznej. Ostatni ( $w$ tej sekcji) wykład - dotyczący problemu powodów i form wykluczenia ujawnionych na podstawie analizy tekstów pochodzących z kronik wiejskich szkół Pomorza - wygłosiła Aneta Lewińska (Uniwersytet Gdański), która analizy językowe odniosła do problemów społecznych - narodowościowych i tożsamościowych - mieszkańców Pomorza w XX wieku.

W równoległej sekcji obrady otworzył referat Doroty Szogun (Uniwersytet Zielonogórski) Wykluczeni wśród wykluczonych. Chorzy psychicznie w dyskursie publicznym. Referentka poddała analizie dwa sposoby łączenia choroby z podmiotem: poprzez użycie czasownika mieć i poprzez użycie czasownika być. Wśród chorób psychicznych dominuje drugi sposób łączenia, a co za tym idzie, $w$ dyskursie publicznym nie choroba jest zagrożeniem, tylko chory, a przekonanie o potrzebie jego wykluczenia społecznego przez izolację - powszechne. Kolejny referat - także związany z leksyką należącą do pola semantycznego choroby psychicznej - wygłosiła Dorota Hamerlok (Uniwersytet Śląski w Katowicach), która poddała analizie znaczenia leksemów kretyn i maniak. Prelegentka przyjrzała się temu, w jaki sposób kontekst sytuacyjny wpływa na znaczenie i nacechowanie emocjonalne analizowanych jednostek leksykalnych. Jako następna głos zabrała Agnieszka Jedziniak (Uniwersytet Śląski w Katowicach). Referentka przyjrzała się językowym granicom w(y)kluczenia. Analizie zostały poddane etymologia i semantyka leksemów inny i obcy, co pozwoliło na dostrzeżenie relacji zachodzących pomiędzy tymi wyrazami. Jako ostatni wykład wygłosił Paweł Baryś (Uniwersytet Śląski w Katowicach), którego interesował negatywny wizerunek islamu i jego wyznawców w polszczyźnie. Uwaga zwrócona została na dominację dyskursu wykluczenia nad dyskursem tolerancji.

Ostatniego dnia konferencji pierwsza część wystąpień została podzielona na dwie równoległe sekcje. Pierwszą z nich - wpisującą się w nurt rozważań nad fenomenem archiwistyki społecznej - otwierał wykład Artura Rejtera (Uniwersytet Śląski w Katowicach) poświęcony archiwum społecznemu wykluczonych oraz możliwości jego badania z uwzględnieniem różnych instrumentów współczesnej lingwistyki. Analizy zostały przeprowadzone na podstawie materiału zaczerpniętego z biblioteki i archiwum Queerstoria działającego przy Stowarzyszeniu Lambda Warszawa. Ze względu na złożony charakter dyskursu wykluczonych $w$ wystąpieniu uwzględnione zostały nie tylko komunikaty werbalne, ale także ikoniczne. Referat Beaty Dudy, Ewy Ficek i Katarzyny Sujkowskiej-Sobisz (Uniwersytet Śląski w Katowicach) dotyczył archiwum społecznego jako korpusu. Autorki ukazały specyfikę archiwum 
językowego i różne wymiary porozumienia wewnątrz i na zewnątrz przestrzeni archiwalnej. Zaprezentowane zostało także narzędzie umożliwiające analizy zasobów archiwalnych, tj. korpus spotkań ze świadkami historii stworzony przy współpracy z konsorcjum CLARIN-PL. Beata Duda i Ewa Ficek w swoim wystąpieniu poruszały z kolei temat cyfrowych archiwów biograficznych stanowiących nową przestrzeń kształtowania się pamięci zbiorowej. Refleksji poddane zostały wybrane cyfrowe „miejsca pamięci”, poświęcone wybitnym postaciom kultury, literatury i sztuki. Referat stanowił także próbę odpowiedzi na pytania dotyczące między innymi tego, kim są twórcy i korzystający z archiwów, kogo się w nich upamiętnia i $w$ jaki sposób sylwetki tych osób są budowane.

Druga sekcja obejmowała dwa referaty. Pierwszy z nich wygłosiła Katarzyna Wyrwas (Uniwersytet Śląski w Katowicach), która zdefiniowała mowę nienawiści, przedstawiła jej obszary tematyczne oraz językowe wykładniki. Objęta refleksją została zawartość postów i komentarzy na facebookowym fanpage'u Ośrodka Monitorowania Zachowań Rasistowskich i Ksenofobicznych, wśród których liczną grupę stanowią przejawy agresji językowej. Waldemar Czachur (Uniwersytet Warszawski) wygłosił referat dotyczący pojednania polsko-niemieckiego w latach 90. XX wieku. Ważną rolę w kontekście tych rozważań odegrało pojęcie kontradykcyjności jako zjawiska społecznego i lingwistycznego. Na przykładzie dyskursu polsko-niemieckiego referent ukazał mechanizmy jego działania i jego językowe wykładniki.

Na obrady plenarne złożyły się dwa ostatnie wystąpienia konferencyjne. Pierwsze z nich wygłosiła Iwona Burkacka (Uniwersytet Warszawski), która poruszyła zagadnienie słowotwórczych sposobów nazywania i opisywania bohaterów powieści Joanny Bator, których wygląd lub zachowanie różni się od dominujących w społeczeństwie, a także słowotwórczych sposobów nominalizacji nietypowych zwierząt i istot fantastycznych. Referentka wykazała, że w analizowanych derywatach utrwalone są opisy włączania bohaterów we wspólnotę lub wypełnianie ról społecznych, z kolei w sposobach ich stosowania można dostrzec mentalność kreowanych postaci. Ostatni wykład w czasie konferencji wygłosiła Marta Wójcicka (Uniwersytet Marii Curie-Skłodowskiej). Został on poświęcony (nie)porozumieniom mediologicznym na podstawie dyskusji, jaką wywołała seria plakatów Tęczowa Matka Boska autorstwa Elżbiety Podleśnej. Referentka zaproponowała traktowanie wspomnianego plakatu jako nośnika pamięci, a punktem wyjścia rozważań stała się typologia pomników - nośników pamięci Regisa Debreya. Umożliwiło to spojrzenie na omawiany tekst kultury z trzech różnych punktów widzenia, a także pozwoliło dostrzec, wynikające z takiego sposobu oglądu, różne (często utrudniające porozumienie) interpretacje i dyskursy.

Wszystkie zaprezentowane referaty zainspirowały słuchaczy do ożywionej dyskusji dotyczącej zagadnień poruszanych $w$ czasie spotkania naukowego. Uczestnicy czerpali z różnych paradygmatów, metodologii i teorii, a referaty niejednokrotnie miały charakter interdyscyplinarny. Zagadnienia zostały zaprezentowane w zróżnicowanych ujęciach: językoznawczym, literaturoznawczym i kulturoznawczym. Ta różnorodność dowodzi, że obszar badań zarysowany przez organizatorów stale cieszy się zainteresowaniem. Niniejszy tekst przybliża jedynie $w$ ogólnym wymiarze prezentowane wystąpienia teoretyczne i analityczno-interpretacyjne, które zostaną zebrane $w$ tomie pokonferencyjnym przygotowywanym przez organizatorów. 